\title{
Rituximab Iodination Procedure for Radioiodinated Rituximab (131I-Rituximab) Preparation
}

\author{
Martalena Ramli, ${ }^{1}$ Basuki Hidayat, ${ }^{2}$ Sutari, ${ }^{1}$ Sri Setyowati, ${ }^{1}$ V. Yulianti Susilo ${ }^{1}$ \\ ${ }^{1}$ Centre for Radioisotope and Radiopharmaceutical Technology, National Nuclear Energy Agency, \\ South Tangerang, Indonesia, ${ }^{2}$ Department of Nuclear Medicine, Faculty of Medicine Universitas Padjadjaran/ \\ Dr. Hasan Sadikin General Hospital Bandung, Indonesia
}

\begin{abstract}
Rituximab is a chimeric monoclonal antibody which has specific for CD20 antigen expressed by pre-B and mature B-cells. Radiolabelled Rituximab, ${ }^{131}$ I-Rituximab, has been sucessfully used for treatment of B-Cell NHL. Due to its short shelf-life, ${ }^{131}$ I-Rituximab is commonly freshly prepared in hospitals prior to its used. This study aimed to validate rituximab iodination procedure for 131I-Rituximab preparation in order to find the most suitable procedure to be applied in hospitals which intend to produce ${ }^{131}$ I-Rituximab in-house. Three different methods of radiolabelling using three types of oxidizing agents, namely Iodobeads, Iodogen, and Chloramine-T were performed. Prior to the validation, radiochemical purity test and purification procedures were also validated as these procedures are critical for producing an acceptable quality of I-Rituximab. In addition, the shelf-life of ${ }^{131}$ I-Rituximab was also studied. This study was conducted at the Centre for Radioisotope and Radiopharmaceutical Technology, Serpong during the period of July 2015 to February 2018. The results showed that the radiochemical purity test of ${ }^{131}$ I-Rituximab could be easily performed by using instance thin layer chromatography-silica gel (ITLC-SG) in the stationary phase and $85 \%$ methanol or saline in the mobile phase. Purification of ${ }^{131}$ I-Rituximab was conducted using a Sephadex G-25 M filled column with 0.1 M PBS, pH 7.2, as the eluent that was found to be quite reliable to give ${ }^{131}$ I-Rituximab with radiochemical purity of $>95 \%$ and recovery of approximately $90 \%$. Radiolabelling efficiency performed using Iodobeads was the lowest (60\%) compared to that of Iodogen and Chloramine-T (80-90\%). In addition, approximately 30\% of I was retained by Iodobeads and this procedure was time consuming( $\sim 1$ hours). It is concluded that Chloramine-T and Iodogen are better than Iodobeads as the oxidizing agent for radiolabelling of Rituximab with ${ }^{131} \mathrm{I}$. The radiochemical purity of ${ }^{131} \mathrm{I}$-Rituximab is well maintained when stored at room temperature and in $4^{\circ} \mathrm{C}$ temperature up to 6 hours.
\end{abstract}

Key words: Rituximab, I-131, radiolabelling procedure, validation

\section{Validasi Prosedur Iodinasi Rituximab untuk Preparasi ${ }^{131}$ I-Rituximab}

\begin{abstract}
Abstrak
Validasi proseduri odinasi rituximab untuk preparasi ${ }^{131}$ I-Rituximab telah berhasil dilakukan. Validasi ini dilakukan untuk mendapatkan prosedur yang paling sesuai yang dapat diaplikasikan untuk produksi ${ }^{131}$ I-Rituximabdi rumah sakit yang ingin memproduksi ${ }^{131}$ I-Rituximab di laboratorium mereka. Tiga metode radiolabelling menggunakan 3 jenis oksidator Iodobeads, Iodogen, dan Chloramine-T telah divalidasi. Sebelum validasi ini, prosedur uji kemurnian radiokimia dan pemurnian divalidasi terlebih dahulu karena prosedur-prosedur ini sangat berpengaruh dalam penyediaan ${ }^{131}$ I-Rituximab dengan kualitas yang baik. Di samping itu, lama simpan ${ }^{131}$ I-Rituximab juga dipelajari. Penelitan ini dilaksanakan di Pusat Teknologi Radioisotop dan Radiofarmaka, Serpong, Juli 2015-Februari 2018. Hasil penelitian memperlihatkan bahwa uji kemurnian radiokimia ${ }^{131}$ I-Rituximab dapat dilakukan dengan mudah menggunakan instance thin layer chromatography-silica gel (ITLC-SG) sebagai fasa diam dan metanol 85\% atau larutan salin sebagai fasa gerak. Pemurnian ${ }^{131}$ I-Rituximab menggunakan kolom Sephadex G-25 M dan 0.1 M PBS pH 7,2 sebagai eluen dapat diandalkan dan memberikan ${ }^{131}$ I-Rituximab dengan kemurnian radiokimia $>95 \%$ dan sekitar 90\% perolehan kembali. Efisiensi penandaaan menggunakan Iodobeads didapatkan paling (60\%) dibanding dengan Iodogen dan Chloramine-T (80-90\%). Di samping itu, sekitar $30 \%{ }^{131}$ I hilang karena terikat pada Iodobeads dan prosedur ini memakan waktu yang panjang ( 1 jam). Penandaan Rituximab ${ }^{131}$ I menggunakan Chloramine-T and Iodogen dapat disimpulkan lebih baik dibanding dengan menggunakan Iodobeads. Kemurnian radiokimia ${ }^{131}$ I-Rituximab terjaga dengan baik pada penyimpanan selama 6 jam pada suhu kamar dan $4{ }^{\circ} \mathrm{C}$.
\end{abstract}

Kata kunci: Rituximab, I-131, radiolabelling procedure, validasi

Corresponding Author: Martalena Ramli, Centre for Radioisotope and Radiopharmaceutical Technology, National Nuclear Energy Agency, PUSPIPTEK Serpong Gedung 11, South Tangerang, Banten 15310, Indonesia, Email: marta_r@batan.go.id 


\section{Introduction}

Rituximabis is a specific chimeric monoclonal antibody for CD20 antigen that is expressed by pre-B and mature B-cells. ${ }^{1}$ Rituximab is approved by the United State Food and Drug Administration (US -FDA) in 1997 for treatment of B-Cell NHL. Since 2006, Rituximab has also been approved for treatment of rheumatoid arthritis that is non-responsive to tumour necrosis factor antagonists. ${ }^{2}{ }^{3}$ The use of Rituximab, in this case, is related to the involvement of B-cells in the inflammation process of rheumatoid arthritis. In order to further enhance response to therapy, Rituximab has also been radiolabelled with Iodine-131( $\left.{ }^{131} \mathrm{I}\right)$, a radionuclide which emits $\beta$ particle with maximum energy of $0.61 \mathrm{MeV}$ and an average energy of $0.192 \mathrm{MeV}$ with tissue penetration range of $0.8 \mathrm{~mm}$ and a half-life of 8.01 days.

Radiolabelled Rituximab, ${ }^{131}$ I-Rituximab, has been sucessfully used for treatment of B-Cell NHL. ${ }^{4}$ Due to its short shelf-life, ${ }^{131}$ I-Rituximab is commonly prepared in hospitals right before its use as a fresh preparation. There have been several reports regarding radiolabeling of Rituximab with ${ }^{131}$ I. Kang et al. ${ }^{5}$ has reported the use of Iodobeads for radiolabeling of Rituximab with ${ }^{131}$ I. This procedure is relatively simple to perform. Iodobeads, an immobilisedoxidising agent, can simply be removed at the end of the radiolabeling procedure. If radiolabeling efficiency for this procedure reaches $\geq 90 \%$, no purification is needed. However, radiolabeling efficiency was not reported in these works. Win et. al. ${ }^{6}$ indicated the use of Chloramine-T for radiolabeling Rituximab with reported radiolabeling efficiency of $98 \%$. The ${ }^{131}$ I-Rituximab produced has to be purified to remove the side products. ${ }^{7}$ Tran et. al. $^{8}$ reported the use other oxidizing agent, Iodogen, for radiolabeling of Rituximab with ${ }^{131}$ I. The reported of radiolabeling efficiency in this procedure was between 80 and 93\%. The ${ }^{131}$ I-Rituximab produced had to undergo purification as performed on the one produced using Chloramine-T.

In recent years, there have been a lot of interests coming from hospitals in Jakarta, Bandung, and Semarang regarding the use ${ }^{131}$ I-Rituximab for B-Cell NHL. These interests have triggered the authors' interest to explore the most suitable radiolabeling procedure for Rituximab using ${ }^{131}$ I that can be easily performed in hospital laboratories. Our preliminary study, where Iodobeads were used as the oxidizing agent in ${ }^{131}$ I-Rituximab radiolabeling resulted in a very low radiolabeling yield. Rradiolabeling yield is one of the important information required by hospitals which intend to perform an in-house production of ${ }^{131}$ I-Rituximab. This information will determine how much ${ }^{131}$ I should be procured for the radiolabeling process and how much fund required for providing certain radioactivity level of ${ }^{131}$ I-Rituximab. This study aimed to validate the reported procedures for radiolabeling of Rituximab with ${ }^{131} \mathrm{I}$. This validation is expected to provide the most suitable procedure that could be applied in hospitals intending to do in-house production of ${ }^{131}$ I-Rituximab. In addition, prior to validation of radiolabeling procedure of Rituximab with ${ }^{131}$ I, radiochemical purity test/quality control and purification procedures were also validated based on the fact that these procedures, to some extent, are critical to produce acceptable quality of ${ }^{131}$ I-Rituximab.

\section{Methods}

This work was conducted at the Centre for Radioisotope and Radiopharmaceutical Technology-National Nuclear Energy of Indonesia (PTRR-BATAN), PUSPIPTEK area, Serpong, from July 2015 to February 2018.

The material used in this project included $\mathrm{Na}^{131} \mathrm{I}$ in $0.05 \mathrm{~N} \mathrm{NaOH}$ solution which was produced in-house at PTRR-BATAN. $\mathrm{Na}^{131}$ I was prepared by irradiating natural $\mathrm{Te}$ target at the G.A. Siwabessy Multi Purposes Reactor for 4 days. The resulted ${ }^{131} \mathrm{I}$, which is a daughter of ${ }^{131} \mathrm{Te}$, was distillated to separate it from the irradiated natural Te target. Other materials were Rituximab/Mabthera (Kalbe Farma), Iodobeads, Iodogen, Chloramine-T (Thermo Scientific), Sephadex G-25M (GE Healthcare), $\mathrm{Na}_{2} \mathrm{HPO}_{4}, \mathrm{NaH}_{2} \mathrm{PO}_{4}$, methanol, acetone, $\mathrm{CHCl}_{3}$ (Merck), saline (IPHA Farma), bovine serum albumin (BSA, Sigma), instance thin layer chromatography-silica gel (ITLC-SG, Agilent), and Whatman Paper No. 1 (Merck).

Equipment used in this project consisted of thermomixer (Eppendorf), dose calibrator (Capintex), gamma counter (Caprac), and other supporting equipments.

Before validating the radiolabeling procedure for Rituximab with ${ }^{131}$ I, radiochemical purity testing and purification procedures were validated as these procedures are critical in producing an acceptable quality of ${ }^{131}$ I-Rituximab to some extent. The radiochemical purity test 
procedure validated in this project was the thin layer chromatography (TLC) using 4 different systems. These systems were a) Whatman Paper No.1 as stationary phase and $75 \%$ methanol as a mobile phase (Whatman No.1/75\% methanol); b) ITLC-SG as stationary phase and $85 \%$ methanol as a mobile phase (ITLC-SG/85\% methanol) ${ }^{7}$; c) ITLC-SG as stationary phase and $100 \%$ acetone as a mobile phase (ITLC-SG $/ 100 \%$ acetone) $^{5}$; and d) ITLC-SG as stationary phase and saline as a mobile phase; (ITLC-SG/saline ). ${ }^{9}$ In this testing, free ${ }^{131} \mathrm{I}$ in the form of $\mathrm{Na}^{131} \mathrm{I}$ or the purified ${ }^{131}$ I-Rituximab was spotted on a test strip, $1 \mathrm{~cm}$ from the bottom of each strip. Each strip was then developed in each representative mobile phase up to $1 \mathrm{~cm}$ from the top of the strip. The strip was then dried and counted for radioactivity using gamma counter.

Purification of ${ }^{131}$ I-Rituximab was performed by passing the product through a Sephadex G 25M filled column (10x0.8 $\mathrm{cm}$ E) treated with $2 \mathrm{~mL} \mathrm{10 \%} \mathrm{BSA.} \mathrm{The} \mathrm{column} \mathrm{was} \mathrm{eluted}$ with $0.1 \mathrm{M}$ PBS pH 7.2 and fractions $(0.5 \mathrm{~mL} /$ fraction) were retrieved. Each fraction was measured for its radioactivity and protein content using a dose calibrator and protein dye, respectively. Fractions, which contained protein and has relatively high radioactivity, underwent radiochemical purity test. ${ }^{9}$

There were 3 procedures for radiolabeling Rituximab with ${ }^{131}$ I that were validated in this project. These procedures involved the use of three different oxidizing agents;Iodobeads, Iodogen, and Chloramine-T. Validation of radiolabeling procedure was performed at least five times for each procedure.

For radiolabeling Rituximab with ${ }^{131}$ I using Iodobeads as an oxidizing agent, Iodobeads were washed twice with $0.1 \mathrm{M}$ phosphate buffered saline aliquot (PBS pH 7.4) and then decanted. $\mathrm{Na}^{131} \mathrm{I}$ aliquot, which had been conditioned with $0.2 \mathrm{M}$ phosphate buffer $\mathrm{pH} 6.5(\mathrm{v} / \mathrm{v}, 1: 1)$, was added to the Iodobeads. This mixture was incubated for 10-60 minutes at room temperature and mixed using thermomixer $(\sim$ $400 \mathrm{rpm}$ ). A Rituximab aliquot (5 mg in $500 \mathrm{~mL}$ ) was then added and the mixture was allowed to react for $10-60$ minutes. ${ }^{5}$ The formation of
${ }^{131}$ I-Rituximab was monitored by the TLC system. Purification of ${ }^{131}$ I-Rituximab was performed by passing the raw product through a Sephadex G $25 \mathrm{M}$ column $(10 \times 0.8 \mathrm{~cm} Æ)$ which had been treated with $2 \mathrm{~mL}$ of $10 \%$ BSA. $^{9}$

Radiolabeling for Rituximab Radiolabeling with ${ }^{131}$ I using Iodogen as theoxidizing agent, Rituximab aliquot ( $5 \mathrm{mg}$ in $500 \mathrm{~mL}$ ) was added to an Iodogen coated tube. The Iodogen coated tube was prepared by adding Iodogen aliquot ( $1 \mathrm{mg} / \mathrm{mL}$ in $\mathrm{CHCl}_{3}$ ) into a clean tube, followed by evaporating the solvent to dryness using $\mathrm{N}_{2}$. $\mathrm{Na}^{131} \mathrm{I}$ aliquot was then added to the tube and the mixture was allowed to react for 2 minutes before the addition of KI solution aliquot $(0.1 \mathrm{mg} / \mathrm{mL})$. The mixture was further left to react for another 2 minutes, followed by radiolabeling efficiency determination using TLC system. Purification was also performed using a Sephadex G 25M filled column $(10 \times 0,8 \mathrm{~cm} Æ)$ which had been treated with $2 \mathrm{~mL}$ of $10 \%$ BSA. $^{8}$

For Radiolabeling Rituximab Radiolabeling with ${ }^{131}$ I using Chloramine-T as the oxidizing agent, Rituximab aliquot ( $5 \mathrm{mg}$ in $500 \mathrm{~mL}$ ) was added into a tube, followed by the addition of $\mathrm{Na}^{131}$ I aliquot. Aliquot of Chloramine-T $(1 \mathrm{mg} / \mathrm{mL})$ was added and the mixture was allowed to react for 4 minutes. The reaction was then terminated by adding $200 \mathrm{~mL} \mathrm{Na} \mathrm{S}_{2} \mathrm{O}_{5}(1 \mathrm{mg} / \mathrm{mL})$. The radiolabeling efficiency of ${ }^{131}$ I-Rituximab was determined using TLC system and purification was performed using a Sephadex G 25M filled column (10 x $0.8 \mathrm{~cm} \mathrm{Æ}))$ which had been pretreated with $2 \mathrm{~mL}$ of $10 \% \mathrm{BSA}^{7}$

Shelf life testing was performed by measuring the radiochemical purity of ${ }^{131}$ I-Rituximab which had been stored at $4^{\circ} \mathrm{C}$ and room temperature for several hours. Radiochemical purity test was performed using the TLC system. ${ }^{9}$

\section{Results}

Four different TLC systems for measuring ${ }^{131}$ I-Rituximab radiochemical purity were validated in this project. The validation results are presented in Figure 1 and Table 1. Figure 1A and Figure $1 \mathrm{~B}$ show a typical radiochromatogram

Table 1 Percentage of Na-131I Found at the Area of $\mathrm{Rf}<0.4$ Developed with four Different Chromatography Systems

\begin{tabular}{ccccc}
\hline \multirow{2}{*}{ TLC System } & $\begin{array}{c}\text { Whatman Paper } \\
\text { No.1/ Methanol 75\% }\end{array}$ & $\begin{array}{c}\text { ITLC-SG/Methanol } \\
\mathbf{8 5 \%}\end{array}$ & ITLC-SG / Acetone & ITLC-SG/Saline \\
\hline${ }^{131} \mathrm{IRf}<0.4$ & $4.0 \pm 1.6 \%$ & $2.1 \pm 0.0 \%$ & $26.0 \pm 16.9 \%$ & $2.9 \pm 1.6 \%$ \\
\hline
\end{tabular}

Note: $\mathrm{N} \geq 5$ 


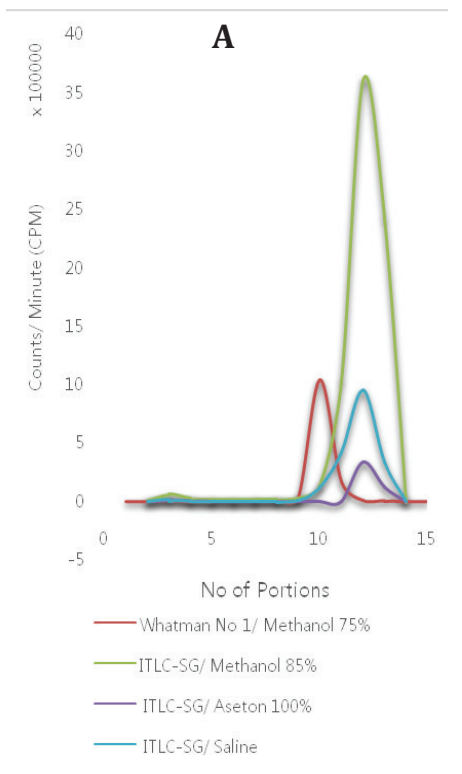

Figure 1A Radiochromatogram of $\mathrm{Na}^{131} \mathbf{I}$

of ${ }^{131} \mathrm{I} / \mathrm{Na}^{-131} \mathrm{I}$ (a starting material in the radiolabeling process of Rituximab) and purified ${ }^{131}$ I-Rituximab, respectively. Figure $1 \mathrm{~A}$ shows that $\mathrm{Na}^{-131}$ I moved with solvent front to give retardation factor (Rf) of $>0.6$ for all TLC systems. The radiolabelled Rituximab, ${ }^{131}$ I-Rituximab, stayed at origin $(\mathrm{Rf}<0.4)$. This figure shows that $\mathrm{Na}^{-131}$ I (radiochemical impurity in ${ }^{131}$ I-Rituximab product) appeared to be well separated from ${ }^{131}$ I-Rituximab. However, not $100 \%$ of $\mathrm{Na}^{131} \mathrm{I}$ was quantitatively found in the area of $\mathrm{Rf}>0.6$; some of the $\mathrm{Na}^{-131}$ I were also found in the area of $\mathrm{Rf}<0.4$, which is there area where ${ }^{131}$ I-Rituximab supposed to appear (Table 1).

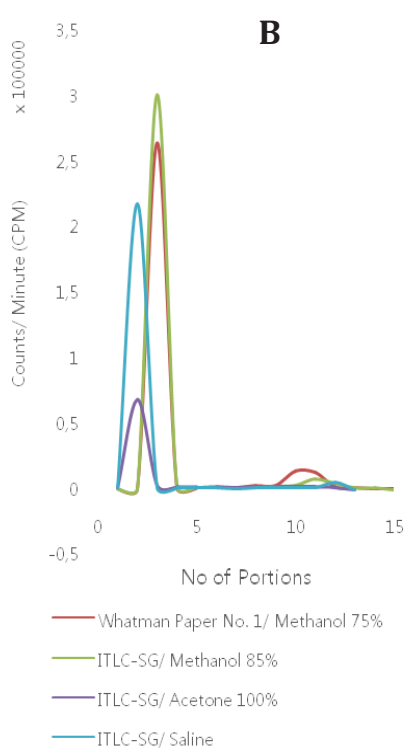

Figure 1B Radiochromatogram of ${ }^{131} \mathrm{I}-$
Rituximab

Percentage of Na-131I found at the area of $\mathrm{Rf}<0.4$ developed with ITLC-SG/Acetone was found significantly higher $(26.0 \pm 16.9 \%)$ compared to other chromatography systems, $4.0 \pm 1.6 \%$ (Whatman Paper No.1/ Methanol $75 \%$ ), $2.9 \pm 1.6 \%$ (ITLC-SG/ saline) and $2.1 \pm 0.0 \%$ (ITLC-SG/ methanol 85\%).

Purification of ${ }^{131} \mathrm{I}$-Rituximab was performed by passing the product on a Sephadex G $25 \mathrm{M}$ filled column which was pre-treated with $2 \mathrm{~mL}$ of $20 \%$ BSA. The retrieved-fractions were determined for their radio activities and protein content. Figure 2 shows a typical radiochromatogram from purification process of ${ }^{131}$ I-Rituximab and

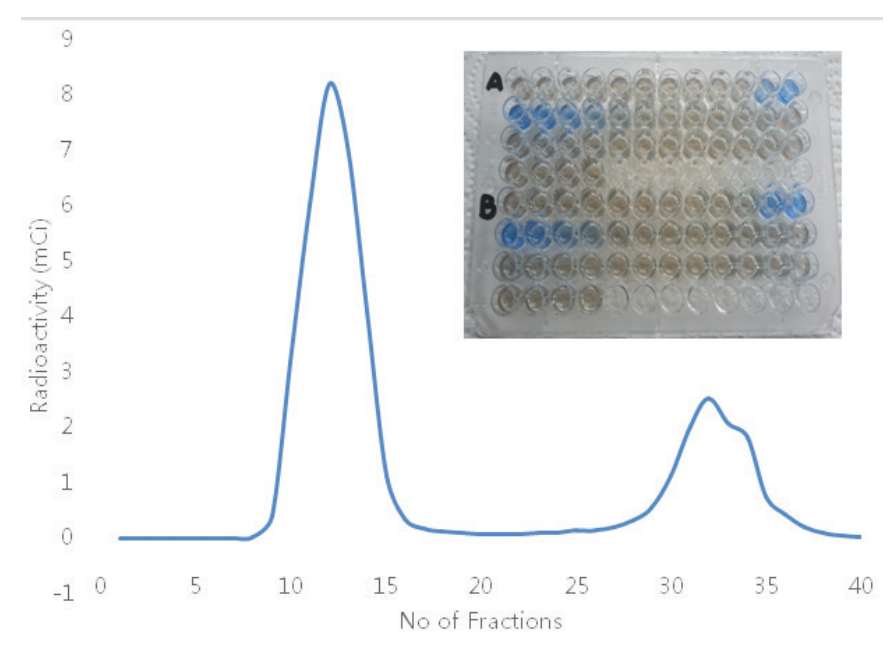

Figure 2 Typical Radiochromatogram of ${ }^{131}$ I-Rituximab Purification Process 


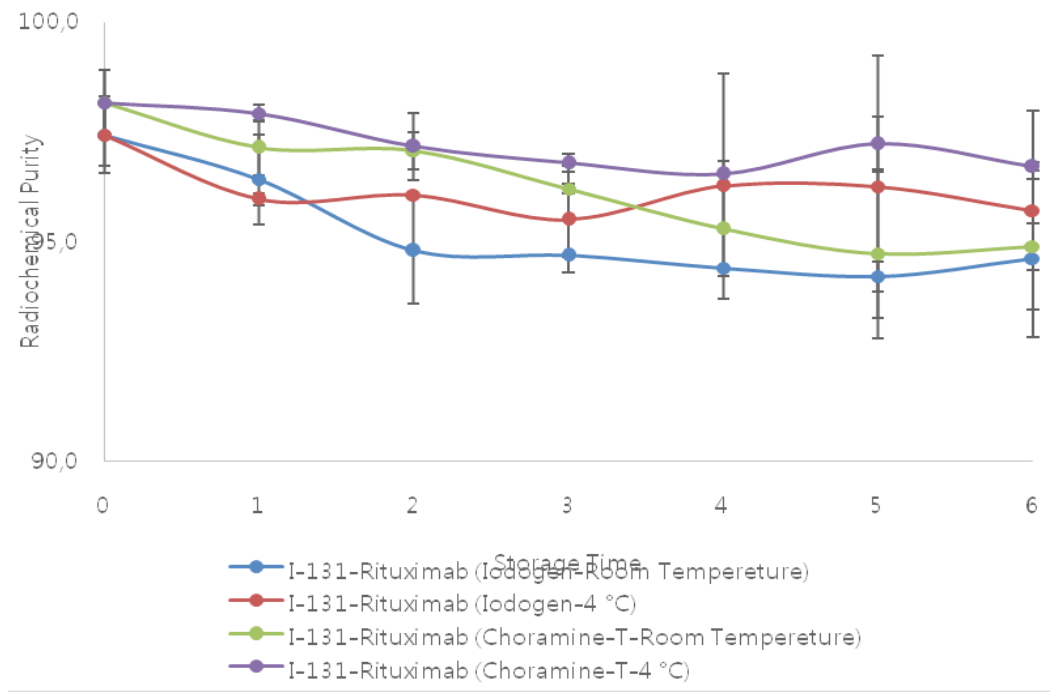

Figure 3 Radiochemical Purity of ${ }^{131}$ I-Rituximab Stored at Room Temperature and $4^{\circ} \mathrm{C}$

fractions which had been tested for their protein content. This figure depicts that fractions 11 to 16 , which had relatively high radioactivity, turned blue when a protein dye was given, indicating that Rituximab had been labelled with ${ }^{131}$ I. In order to discover the radiochemical purity of fractions containing protein, each fraction was tested for its radiochemical purity using the TLC system.

Radiochemical purity of purified 131IRituximab test results showed fractions 10 to 13 gave an average radiochemical purity of $97.9 \pm$ $0.7 \%$, while radiochemical purity for fractions 14 and 15 were $95.8 \pm 4.3$ and $95.0 \pm 1.3 \%$ respectively. As the percentage of SD for these fractions are 4.3 and $1.3 \%$, the radiochemical purity for theses fractions could be between 91-100.2 and 93.8-96.4\% respectively. As the radiochemical purity for these fractions were slightly closer to the lowest percentage allowed for a good radiopharmaceutical agent, these fractions were not collected. Fractions 10-13 were only pooled as 131I-Rituximab product.

Radiolabeling validation for Rituximab with Na131I was performed using three different oxidizing agents, namely Iodobeads, Iodogen, and Chloramine-T, ${ }^{5,78}$ The percentage of radiolabeling efficiency and their recovery after purification is shown in Table 1.

Table 1 shows that radiolabeling using Iodogen and Chloramine $\mathrm{T}$ gave a percentage of radiolabeling of between $80-90 \%$. As the percentage of purification recovery reached $90 \%$, the percentage of total recovery of purified 131I-Rituximab reached 70-80\%. Radiolabeling using Iodobeads only gave a maxmium percentage of radiolabeling efficiency of $60 \%$ with one-hour incubation time. Radiolabeling

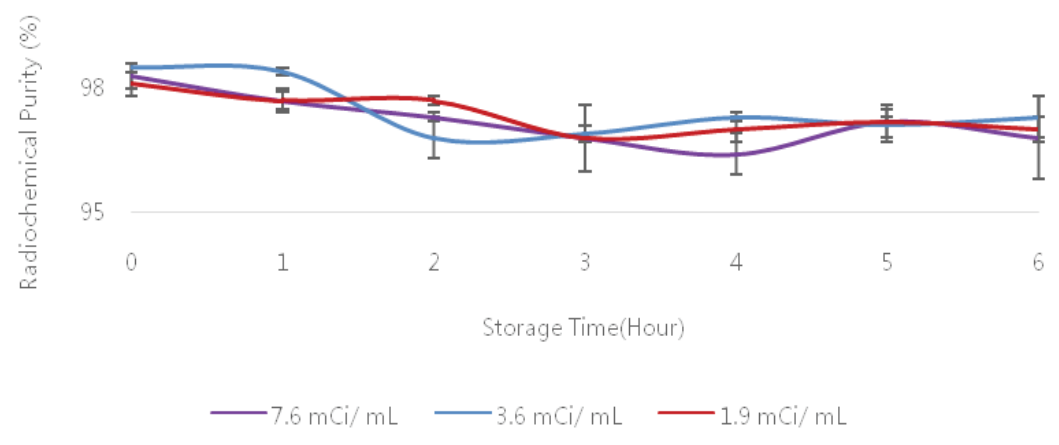

Figure 4 Radiochemical Purity of ${ }^{131}$ I-Rituximab Stored at $4^{\circ} \mathrm{C}$ 


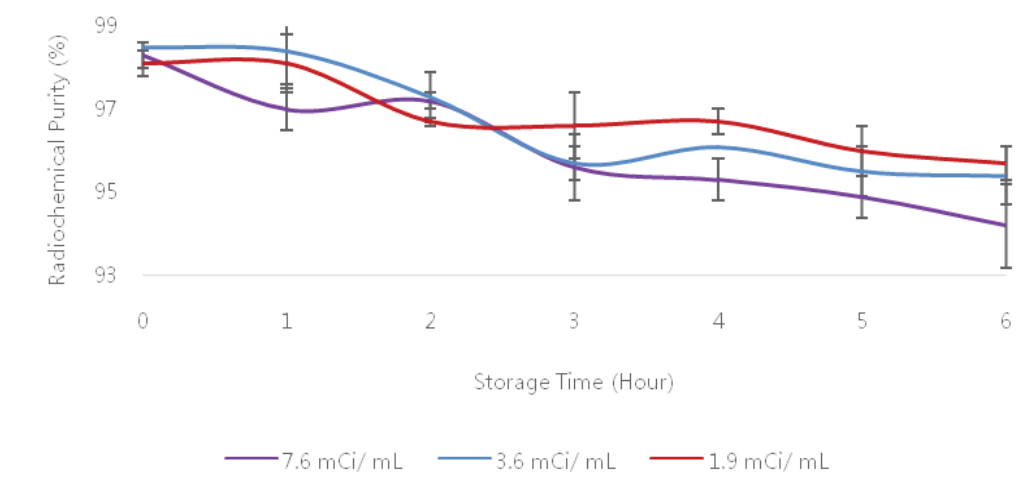

Figure 5 Radiochemical Purity of ${ }^{131}$ I-Rituximab Stored at $22^{\circ} \mathrm{C}$

with less than one hour incubation time (1040 minutes) gave much lower radiolabeling efficiency. In addition, an average of $30 \%$ of 131I starting material was found to be still attached to Iodobeads despite the radiolabeling process. Hence, the total percentage of purified 131I-Rituximab recovered was approximately $38 \%$.

A shelf life test of ${ }^{131}$ I-Rituximab stored at $4{ }^{\circ} \mathrm{C}$ and room temperature was performed to gain information on how long ${ }^{131}$ I-Rituximab with acceptable radiochemical purity could be stored in a certain condition. The shelf life was measured by determining the radiochemical purity of ${ }^{131}$ I-Rituximab stored at $4^{\circ} \mathrm{C}$ and room temperature $\left(22^{\circ} \mathrm{C}\right)$. Figure 4 shows the radiochemical purity of ${ }^{131}$ I-Rituximab (prepared using Iodogen and Chloramin-T) with an average radioactivity concentration of $13.5 \mathrm{mCi} / \mathrm{mL}$ when stored at $4^{\circ} \mathrm{C}$ and room temperature $(22$ ${ }^{\circ} \mathrm{C}$ ). Figure 4 shows how the radiochemical purity of ${ }^{131}$ I-Rituximab prepared using either Iodogen or Chloramin-T, decreased from $98 \%$ to $~ 94 \%$ when stored at room temperature for up to 6 hours. Figure 4 also shows how radiochemical purity of ${ }^{131}$ I-Rituximab prepared using either Iodogen or Chloramin-T, decreased slightly from $\sim 98 \%$ to $\sim 96 \%$ when stored at $4{ }^{\circ} \mathrm{C}$ up to 6 hours.

Figure 4 and 5 show the radiochemical purity situation of ${ }^{131}$ I-Rituximab with lower radioactivity concentration when stored at room temperature and at $4{ }^{\circ} \mathrm{C}$ for up to 6 hours. Figure 4 shows that radiochemical purity of ${ }^{131}$ I-Rituximab (1.9-7.6 mCi/mL) slightly decreased from $\sim 98 \%$ to $\sim 97 \%$ when stored at $4^{\circ} \mathrm{C}$ up to 6 hours. It also shows that ${ }^{131}$ I-Rituximab with different radioactivity concentrations (1.9 $-7.6 \mathrm{mCi} / \mathrm{mL}$ ) stored at $4^{\circ} \mathrm{C}$ did not seem to affect its radiochemical purity.

Figure 5 shows that radiochemical purity of ${ }^{131}$ I-Rituximab (1.9-3.6 mCi/ mL) which was stored at $22^{\circ} \mathrm{C}$ decreased from around 98 to $96 \%$ within 6 hours. However, radiochemical purity of ${ }^{131}$ I-Rituximab with higher radioactivity concentration $\quad(7.6 \mathrm{mCi} / \mathrm{mL})$ decreased significantly from $98 \%$ to around $95 \%$ after 3 hours of storage and further decreased to $<95 \%$ after 6 hours of storage.

\section{Discussion}

Radiochemical purity of a radiopharmaceutical agent is defined as the proportion of the total radioactivity in a samplepresenting as the desired radiolabelled species. Radiochemical purity must conform to the required standard as it will define the biodistribution/uptake when radiopharmaceutical is injected to the human. According to the U. S. Pharmacopoeia National Formulary, radiochemical purity of radiopharmaceutical-based radiolabelled monoclonal antibody, both for diagnosis or therapy, should not be less than $90 \%$. Therefore, each radiopharmaceutical agent intended for diagnosis use or therapy should have itsradiochemical purity examined prior to use. ${ }^{10}$

Since ${ }^{131}$ I-Rituximab is intended to be a hospital-based prepare radiopharmaceutical agent, the radiochemical purity test method has to be relatively simple, quick, and reliable. Four TLC systems were tested for these purposes. Based on the experiment results (Figure 1 and 
2), $\mathrm{Na}^{131}$ I was found to have an $\mathrm{Rf}$ of $>0.6$ and ${ }^{131}$ I-Rituximab had an $\mathrm{Rf}$ of $<0.4$. However, trace of $\mathrm{Na}^{131}$ I was still found where ${ }^{131}$ I-Rituximab was supposed to stay. The lowest trace of $\mathrm{Na}^{131} \mathrm{I}$ found at ${ }^{131} \mathrm{I}$-Rituximab area were $2.1 \pm 0.0 \%$ and $2.9 \pm 1.6 \%$ for ITLC-SG/85\% methanol and ITLC-SG/saline, respectively, and then followed by $4.0 \pm 1.6 \%$ for Whatman Paper No.1/Methanol 75\%. ITLC-SG/Acetone system, however, presented a very high trace of $\mathrm{Na}^{131}$ I at ${ }^{131}$ I-Rituximab area $(26.0 \pm 16.9 \%)$.

TLC is a separation technique which is commonly used for measuring radiochemical purity of radiopharmaceuticals. This technique is relatively simple and inexpensive. This separation technique is based on the ability of each component of the mixture to dissolve between two phases, static and mobile. The systems tested in this project were Whatman Paper No.1/Methanol 75\%, ITLC-SG/methanol 85\%, ITLC-SG/Acetone, andITLC-SG/saline. Out of these systems, ITLC-SG/85\% methanol and ITLC-SG/saline gave better separation compared to others. Saline and $85 \%$ methanol are polar solvents. In the separation of ${ }^{131}$ I-Rituximab, which is less polar from $\mathrm{Na}^{131}$ I as impurity, ${ }^{131}$ IRituximab would be expected to stay at the origin, while $\mathrm{Na}^{131}$ I moves with the polar solvent such as saline and $85 \%$ methanol. Unlike the above-mentioned solvents, acetone is less polar compared to saline and $85 \%$ methanol; therefore, $\mathrm{Na}^{131}$ I was expected not to be properly dissolved and moved by this solvent which in turn gave a relatively high percentage of $\mathrm{Na}^{131}$ I at the origin area of ${ }^{131}$ I-Rituximab. ${ }^{11}$

Purification of ${ }^{131}$ I-Rituximab from its impurity $\left(\mathrm{Na}^{131} \mathrm{I}\right)$ was performed using gravity gel filtration chromatography with a Sephadex G-25 M filled-column. The separation in this chromatography is based on molecular weight (MW) of the compounds which are going to be separated. Compound with high MW will come out first and then followed by compound with lower molecular. ${ }^{131}$ I-Rituximab and $\mathrm{Na}^{131}$ I have molecular mass of $\sim 150 \mathrm{kD}$ and $150 \mathrm{Da}$, respectively. Therefore, in this chromatography ${ }^{131}$ I-Rituximab come out first as expected, followed by $\mathrm{Na}^{131}$ I (Figure 2). In the gravity gel filtration chromatography, eluent flow rate has to be properly maintained in order to have a good separation between ${ }^{131}$ I-Rituximab and $\mathrm{Na}^{131}$ I. ${ }^{131}$ I-Rituximab in this project was able to be well separated from $\mathrm{Na}^{131}$ I when using a Sephadex G-25 M filled column (10 x $1.2 \mathrm{~cm} \mathrm{Æ)}$ with a flow rate of $100 \mathrm{~mL} /$ minute. $^{9}$

Radiolabeling of monoclonal antibody with radioactive iodine such as ${ }^{131} \mathrm{I},{ }^{123} \mathrm{I}$, or ${ }^{124}$ I involves substitution of proton with iodine at certain sites of monoclonal antibody. In order for this substitute to occur, iodine radionuclide, which is available in form of $\mathrm{I}$,has to be oxidized to form $\mathrm{I}^{+}$. This reactive species will then substitute the proton at the phenolic ring of the tyrosineas primary site or at the imidazole ring of histidine as a secondary site. There are a couple of oxidizing agents that are commercially available in the market, namely Iodobeads, Chloramine-T, and Iodogen. ${ }^{12}$ Kang et al. ${ }^{5}$, Win et al. ${ }^{7}$, and Tran et $a .^{8}$ have reported the use of these oxidizing agents.

Based on radiolabeling process validation results, Iodobeads were shown to be the most unfavourable oxidizing agent for monoclonal antibody radiolabeling. Unlike Iodogen and Chloramine- $\mathrm{T}$, Iodobeads that immobilised Chloramine-T analogue, was prepared with the intention to reduce the rate of iodine incorporation to macromolecules, such as to monoclonal antibody. Hence, a milder radiolabeling environment was expected and protein degradation or activity loss could be avoided. However, this intention has disadvantages. According to our experience, this radiolabeling process is time-consuming (60 minutes) and gives a maximum radiolabeling efficiency of $60 \%$. In addition to its low radiolabeling efficiency, $30 \%$ of starting material $\left(\mathrm{Na}^{131} \mathrm{I}\right)$ was still bound or consumed by Iodobeads at the end of the radiolabeling process. Unak T et. al. also reported that $10-20 \%$ of the starting material $\left(\mathrm{Na}^{131} \mathrm{I}\right)$ was consumed by Iodobeads. ${ }^{13}$ Low radiolabeling efficiency and self-consumption of starting material $\left(\mathrm{Na}^{131} \mathrm{I}\right)$ by Iodobeads might be caused by the formation of an intermediate reactive species of Iodobeads, $\mathrm{N}$-iodobenzenesulfonamide, prior to the incorporation of Ito the monoclonal antibody as suggested by Markwell. ${ }^{14}$

Radiolabeling Monoclonal antibody radiolabeling with $\left(\mathrm{Na}^{131} \mathrm{I}\right)$ using Iodogen or Chloramin-T as oxidizing agent is a relatively straightforward procedure. It takes only a couple of minutes for incubation and is followed by raw product purification. Radiolabeling efficiency by using these oxidising agents reached $80-90 \%$ meaning it issignificantly higher compared to the one using Iodobeads. Unlike Iodobeads, Iodogenand Chloramin-T have not formed intermediate form with I; instead it is directly oxidise $\mathrm{I}^{-}$to form $^{+}$which attack radiolabelled monoclonal antibody. ${ }^{12}$ This mechanism might explain why radiolabeling using these oxidising 
agents provide a relatively higher percentage of radiolabeling and without any of $\mathrm{Na}^{131}$ I selfconsumed by oxidising agent.

The shelf life test for ${ }^{131}$ I-Rituximab was performed to determine how long ${ }^{131}$ I-Rituximab could be stored while maintaining its radiochemical purity $(>90 \%)$. The results indicated that radiochemical purity of ${ }^{131}$ I-Rituximab (prepared using either Iodogen or Chloramin-T) with an average radioactivity concentration of $13.5 \mathrm{mCi} / \mathrm{mL}$ that was stored at the room temperature $\left(22^{\circ} \mathrm{C}\right)$ for up to 6 hours decreased from $\sim 98 \%$ to $\sim 94 \%$. These radiochemical purities still conform to radiochemical purity of monoclonal antibody based on the radiopharmaceuticals $(>90 \%){ }^{10}$ Similar results were also seen for I-Rituximab (prepared using either Iodogen or Chloramin-T) with an average radioactivity concentration of $13.5 \mathrm{mCi} / \mathrm{mL}$ that is stored at $4^{\circ} \mathrm{C}$ for up to 6 hours in terms of its ability to maintain its radiochemical purity (96\%).

Absorbed dose and storage temperature are reported to have some influences on radiochemical purity of radiopharmaceuticals. Our results show that ${ }^{131}$ I-Rituximab with a radioactive concentration between (1.9-7.6 $\mathrm{mCi} / \mathrm{mL}$ ) and which was stored at $4{ }^{\circ} \mathrm{C}$ was able to maintain its radiochemical purity (> $90 \%$ ) for up to 6 hours. On the other hand, ${ }^{131}$ I-Rituximab $(1.9-3.6 \mathrm{mCi} / \mathrm{mL})$ which was stored at $22{ }^{\circ} \mathrm{C}$ experienced a decrease in its radiochemical purity from around 98 to $96 \%$ within 6 hours. However, ${ }^{131}$ I-Rituximab with a higher radioactivity concentration $(7.6 \mathrm{mCi} /$ $\mathrm{mL}$ ) experienced a significant decrease in its radiochemical purity from $98 \%$ to around $95 \%$ up to 3 hours of storage and further decreased to below $95 \%$ when it was stored at the room temperature for 6 hours.

The decrease of ${ }^{131}$ I-Rituximab radiochemical purity during storage might be caused by radiolysis and storage temperature. It has been reported that the rate of radiolysis will increase with higher absorbed doses of radiation. ${ }^{15131}$ I-Rituximab with radioactivity concentration of $7.6 \mathrm{mCi} / \mathrm{mL}$ would be expected to absorb a higher radiation dose than that with a radioactive concentration of 1.9-3.6 $\mathrm{mCi} / \mathrm{mL}$. Therefore, the chemical bond breakdown between iodine and protein would be expected to be higher in the former, which in turn contributes to a faster decrease in the radiochemical purity. Storage temperature might also contribute in increasing of radiolysis. It was stated that radiopharmaceuticals stored at a low temperature are less susceptible to radiolysis when compared to those stored at a higher temperature. ${ }^{16}$

\section{Acknowledgement}

Authors would like to thank Dr. Rohadi Awaludin and Dra. Siti Darwati, M.Sc, Head and Former Head of Centre for Radioisotope and Radiopharmaceutical Technology, Nuclear Energy Agency of Indonesia for giving permission to do this project. We also would like to thank you to Mr Sriyono and his team for providing us ${ }^{131}$ I for this project.

\section{References}

1. Cannon AC, Loberiza FR. Review of antibodybased immunotherapy in the treatment of non-Hodgkin lymphoma and patterns of use. Clin Lymphoma Myeloma Leuk. 2015;15(3):129-138.

2. Wendler J, Burmester GR, Sörensen H, Krause A, Richter C, Tony H-P, et al. Rituximab in patients with rheumatoid arthritis in routine practice (GERINIS): six-year results from a prospective, multicentre, non-interventional study in 2,484 patients. Arthritis Res Ther. 2014;16(2):R80.

3. Mok CC. Rituximab for the treatment of rheumatoid arthritis: an update. Drug Des Devel Ther. 2013;8:87-100.

4. Leahy MF, Turner JH. Radioimmunotherapy of relapsed indolent non-Hodgkin lymphoma with 131 I-rituximab in routine clinical practice : 10-year single-institution experience of 142 consecutive patients. Blood. 2011;117(1):45-52.

5. Kang HJ, Lee SS, Kim KM, Choi TH, Cheon GJ, Kim WS, et al. Radioimmunotherapy with 131 I-rituximab for patients with relapsed / refractory B-cell non-Hodgkin 's lymphoma (NHL). Asia Pac J Clin Oncol. 2011;7:136145.

6. Shin DY, Byun BH2, Kim KM, Kang JH, Lim I, Kim BI, et al. Radioimmunotherapy with 131 I-rituximab as consolidation therapy for patients with diffuse large B-cell lymphoma. Cancer Chemother Pharmacol. 2016;78(4): 825-31

7. Kuan JW, Law CS, Wong XQ, Ko CT, Awang ZH, Chew LP, et al. A pioneer experience in Malaysia on In-house Radio-labelling of 131 I-rituximab in the treatment of 
Non-Hodgkin's Lymphoma and a case report of high dose 131 I-rituximab-BEAM conditioning autologous transplant. Appl Radiat Isot. 2016;116:13-21.

8. Tran L, Baars JW, Maessen HJ, Hoefnagel CA, Beijnen JH, Huitema AD. A simple and safe method for 131I radiolabelling of rituximab for myeloabative high-dose radioimmunotherapy. Cancer Biother Radiopharm. 2009;24(1):103-10.

9. Ramli M, Hidayat B, Rustendi CT, Subur M, Ardiyatno CN, Karyadi, et al. In vitro and in vivo testing of $177 \mathrm{Lu}$-DOTA-Nimotuzumab, a Potential Radioimmunotherapeutical Agent Of Cancers. ITB J Sci. 2012;44(4):333-45.

10. USP. USP35 NF30, 2012: U. S. Pharmacopoeia National Formulary, The United States pharmacopeia, 2011 United States Pharmacopeial Convention 12601, Twinbrook Parkway, Rockville, MD 20852. 2012:1-38.

11. Ahmad A, Qasimullah, Andrabi A, Qureshi PM. Solvent Solvent polarity as a function of $\mathrm{Rf}$ in thin-layer chromatography of selected nitro functions. J Chromatogr Sci. 1996;34(8):376-8.

12. Hermanson GT. Bioconjugate Techniques. $2^{\text {nd }}$ ed. United States: Academic Press; 2008.

13. Unak T, Akgün Z, Yildirim Y, Duman Y, Erenel G. Self-radioiodination of Iodogen. Appl Radiat Isot. 2001;54(4):749-52.

14. Markwell MA. A new solid-state reagent to iodinate proteins. I. Conditions for the efficient labeling of antiserum. Anal Biochem. 1982;125(2):427-32.

15. Scott PJ, Hockley BG, Kung HF, Manchanda R, Zhang W, Kilbourn MR. Studies into radiolytic decomposition of fluorine-18 labeled radiopharmaceuticals for positron emission tomography. Appl Radiat Isot. 2009;67(1):88-94.

16. Martin PA, da Silva JL, Ramos MPS, de Oliveira IM, Felgueiras CF, Herrerias $\mathrm{R}$, et al. Radiochemical stability of radiopharmaceutical preparations. Intenational Nuclear Atlantic ConferenceINAC 2011; 2011 October 24-28. Belo Horizonte, MG, Brazil: ABEN; 2011. p. 1-6. 